\title{
CREATION OF THE IMAGE AND BRAND OF THE ENTERPRISE ON THE BASIS OF MARKETING AS A PHILOSOPHY OF MANAGEMENT
}

\author{
Diana Raiko', Viktoriia Cherepanova²
}

\begin{abstract}
The modern development of an enterprise is possible only on the basis of marketing since the enterprise is effective only in case of its usefulness for consumers, the relation with which is one of the main marketing functions, i.e., marketing is a philosophy of management. The purpose of the paper is to study the theoretical background and practice of interaction of image and brand of an enterprise on the basis of marketing as a philosophy of management. Methodology. Approbation of the results is presented on the example of business projects for 2017 and 2018 of enterprises with different business scales in Kharkiv and Kharkiv region of Ukraine: small - the Centre for Child Development "Cute Kids", medium - Association of Confectionery Enterprises "Solodkyi Svit" ("Sweet World"), large Turboatom JSC, by means of research methods: theoretical generalization, system approach, expert estimation method. Results. The work results are the development of methodological approach to evaluating the effectiveness of the marketing department in the process of business management at the enterprise, taking into account the enterprise value and brand value for large industrial enterprises, the peculiarity of which is the ability to investigate the relationship between the effectiveness of the development of the marketing department (organizational and managerial aspect) and the performance of its divisions (economic aspect) and take into account the identified causal relationships in the process of enterprise activity. The system for evaluating the performance of the marketing department, taking into account enterprise value and brand value, involves two levels of assessment: the first one allows determining its performance in general, that is, the effectiveness of its development, the second one takes into account the specifics of divisions of this department of the enterprise and allows determining their performance according to individual results, that is, the effectiveness of divisions, which is reflected in the basic social and economic performance indicators of the enterprise. The effectiveness of the development of the marketing department is evaluated using the following indicators: development trend ratio, marketing efficiency ratio, management process productivity ratio, division productivity ratio, and executive efficiency ratio. The calculation is based on individual indicators: an integral indicator of the effectiveness of the development of the marketing department, which is calculated by the normalized part of the indicators for additive convolution, taking into account their ratios of significance, and by performance indicators of marketing research division (sales volume, market share, building market strength), the work of the business development division is evaluated using indicators ("corporate image", "enterprise competitiveness", "profit", "consumer readiness", "partner's business attractiveness"), communication division (trade turnover, information base update, development of partner relations, brand value), which are interrelated, interdependent, reveal the essence of determining the performance of the marketing department at different angles, allow justifying the adjustment of certain aspects of marketing development at the enterprise, and are calculated as arithmetic mean values of performance indicators of the divisions. Conclusions. Practical approbation of the proposed approach is presented on the example of large industrial enterprise named Turboatom JSC and confirms the practical value of the worked out approach to evaluating the performance of the marketing department in the process of managing the activities of an industrial enterprise, taking into account enterprise value and brand value.
\end{abstract}

Key words: image, brand, marketing, enterprise, evaluation of performance of marketing department.

JEL Classification: M30, M31

\footnotetext{
Corresponding author:

${ }^{1}$ National Technical University “Kharkiv Polytechnic Institute”, Ukraine.

E-mail: diana.raiko2016@gmail.com

ORCID: http://orcid.org/0000-0002-9307-103X

${ }^{2}$ National Technical University “Kharkiv Polytechnic Institute”, Ukraine.

E-mail: vitcherepanova@gmail.com

ORCID: https://orcid.org/0000-0002-0294-1678
} 


\section{Introduction}

In modern conditions, successful creation and conduct of business are impossible without constant adaptation to changes in market conditions, which are characterized by its dynamism and, often, unpredictability. At the same time, the main means of adapting to changes in the market environment is the use by an enterprise of marketing management concept, which among other elements includes information and emotional impact on target consumer audiences, which is the basis for the interrelation of the brand and the image of the enterprise. When choosing an enterprise product or a service, the consumer has to be guided mainly by the enterprise image because, in order to make a decision about the purchase, its use does not almost allow getting a clear understanding of the quality and competitive advantages.

In terms of modern economy, enterprise competitiveness largely depends on the maintenance of an effective functioning organizational structure of marketing. All this, in its turn, determines the need for organizational transformations, the creation of new marketing organizational structures, which to the greatest extent meet the enterprise goals, requirements, business forms, and market.

The image cannot be considered without the developed brand because a well-designed brand is not only the external attributes of the enterprise and the product; it is a conceptual policy that is the key to building a strong image of the enterprise in the market. An important factor in working on the image is both informational and emotional, and also the evaluativevalue position of influence on the target audience of consumers in order to determine the enterprise competitiveness.

While studying the image and brand of the enterprise, little attention is paid to the study of their relationship. In addition, the concepts of "image" and "brand" are often confused in practice, which necessitates the further detailed study of these concepts and their interconnection. This explains the choice of the topic of this work, emphasizes its relevance, practical importance.

The purpose of the paper is to study theory and practice of interaction of image and brand of an enterprise on the basis of marketing as a philosophy of management on the example of enterprises with different business scales: small, medium, and large, and to substantiate practical recommendations for ensuring economic development in the current economic environment. In particular, to determine interrelation of image, brand; enterprise image as an integral part of brand with the help of a complex of marketing communications; develop methodological provision for performance evaluation of the marketing department in the process of management of activities on the example of a large enterprise taking into account corporate image, enterprise value, brand value according to organizational and managerial and also economic aspects by two levels of assessment: the first one allows determining its performance in general, that is, the effectiveness of its development, the second takes into account the specifics of divisions of this department of the enterprise and allows determining their performance according to individual results, that is, the performance of divisions.

Practical implementation of research results is presented on the example of business projects of enterprises with different business scales in Kharkiv and Kharkiv region of Ukraine: small - the Centre for Child Development "Cute Kids", medium-sized - Association of Confectionery Enterprises "Solodkyi Svit" ("Sweet World"), and large - Turboatom JSC.

\section{Literature review}

Both domestic and foreign scientists have contributed to the study of the essence of the enterprise image and brand. Thus, B. Gardner considered the image as a collection of knowledge, representations, and predictions of a person about the object and its environment (Gardner, Levy, 1955), C. Sandage seemed image as a portrait fixed on the brand, as important as any appreciable characteristics of the product, if not more (Sandage, 2001).D. Ogilvy wrote that image of a product means a unique composition of qualities that are firmly rooted in the thoughts and feelings of people (Ogilvy, 2003). S. Oliver believed that image is a mental picture; an idea, generated by imagination, or a personality in the representations of man, organization (Oliver, 2003). I. V. Aleshina distinguishes corporate image - it is the image of the organization in the presentation of social groups (Aleshina, 1998). V. Ya. Zaruba described the concept "image" as a specially designed, based on the peculiarities of activity, patterns, properties, advantages, qualities, and characteristics of the image of a certain object, which is purposefully introduced (fixed, entangled) in the consciousness of target audiences with the help of marketing communications mix (Zaruba, Shasha, 2001).

Interbrand company describes brand as "name, concept, sign, symbol, design, or a combination of the above properties intended to identify goods or services offered by the seller, as well as to distinguish them from the goods and services of competitors, and as a set of all explicit and implicit characteristics that make the offer unique" (Interbrand World's Most Valuable Brands 2001 Methodology). Peter Doyle said about brand that it is a product set that satisfies the functional needs of consumers and an added value that prompts the consumer to enjoy the fact that the chosen brand is better suited to him because he has advantages over competitors (Doyle, 1999). G. R. Dowling says that a brand - a collection of names 
and other characters and a "promise" that is given to the buyer (Dowling, 2006). J. Jones looks at a brand as a product that meets the functional needs of some users and gives them some added value, contributing to the satisfaction of psychological needs and encouraging the purchase (Jones, 2005). O. V. Dobrianska considers a brand as a trademark that has reached a certain level of reputation (Dobrianska, 2001). M. Kupchynska proposed a brand as "product + name + associations + emotions” (Kupchynska, 2004). O. V. Zozulov believes that a brand is a well-differentiated trademark, that is, which in the minds of consumers is associated with certain advantages or benefits, clearly distinguished from among the brands of competitors and is characterized by a high level of loyalty from consumers (Zozulov, 2003; Zozulov, 2002; Zozulov, Pysarenko, 2004). Laureate of the Nobel Prize in Economics $\mathrm{R}$. Thaler considered brand and image of the behavioural economy as a set of emotions caused by the product and company (Posylannia na dzherelo Premii Shvedskoho natsionalnoho banku $\mathrm{z}$ ekonomichnykh nauk pamiati Alfreda Nobelia).

However, despite a large number of works devoted to these issues, the problems of studying the image, the brand of the enterprise remain relevant and need further search for solutions.

\section{Marketing as a philosophy of enterprise management}

An open socio-economic system, the example of which is an enterprise, falling under the influence of various positive and negative factors of the external environment, gradually changes its qualitative state, which is accompanied by the transformation of its internal and external relations, and as a result the development of a complex socio-economic system, which requires continuous and quality management. Such management of enterprise development as a socioeconomic system is provided exclusively by marketing activity. Therefore, modern enterprise development is possible only on the basis of marketing activity, and marketing - management philosophy.

\section{Image and brand of the enterprise as factors of competitive struggle}

In a context of tight market competition between enterprises that offer identical goods and services, the issue of penetrating a market and attracting a potential client is exacerbated. One of the key factors of competition is the positive image of the enterprise formed in the minds of consumers (Figure 1), which is a means of achieving competitive advantage (Raiko, 2010).

The analysis of existing literary sources allowed us to propose an own definition of the essence of concepts of the image and the brand of the enterprise (Figure 2, 3).
Image of the enterprise is a certain prevailing view of the target audience of consumers about the enterprise, which is based on a consistent increase in knowledge about it and the enhancement of its emotional perception; the image is interrelated with the components of the enterprise activity and depends on a certain set of measures that are implemented in order to maintain and increase it.

Brand of the enterprise - reflection of the individuality of the given enterprise, its competitiveness, advantages of goods or services using the means of informational and emotional impact on consumers, which is a combination of functional and emotional characteristics existing in the minds of consumers and prompting them to choose the goods or services of this enterprise.

The theoretical analysis of the existing ones allows drawing the following conclusions: enterprise image and brand play an equally important role in the context of the competitiveness of enterprises in terms of diversification of business activities; image improvement and brand promotion of the enterprise are carried out by means of marketing communications mix; enterprise image is a part of enterprise brand.

\section{Practical realization of theoretical studies on the interaction of the brand and image is represented on the example of business projects of enterprises with different business scales in Kharkiv and Kharkiv region of Ukraine: small - the Centre for Child Development "Cute Kids", medium - Association of Confectionery Enterprises "Solodkyi Svit", and large - Turboatom JSC}

Small business. According to the results of conducted marketing studies in the market for child development centres in Kharkiv and services, one can draw conclusions that target consumer audience is interested in the satisfaction of the following: caring for children, quality teaching; the comprehensive development of children, the availability of "family" classes, interest and satisfaction of children. Name "Cute Kids" and brand are proposed, and the logo, presented in Figure 4, is developed, which reproduces the main mission of the centre - the formation of comprehensive development of children from the very early age.

Medium-sized business. According to the results of marketing studies in the confectionery market, the creation of a new brand of a commodity group of premium class for consumers is proposed - a series of sweets in a box under one brand, which will include 4 types of sweets (different tastes) with attachments: an insert card with traditions of celebrating Ukrainian holidays.

As a result of the study, based on the focus group, the name "Patria" - fatherland, native land is proposed, slogan: "Patria" - sweet patriotism; a complex system of visual identification of the corporate style is developed 


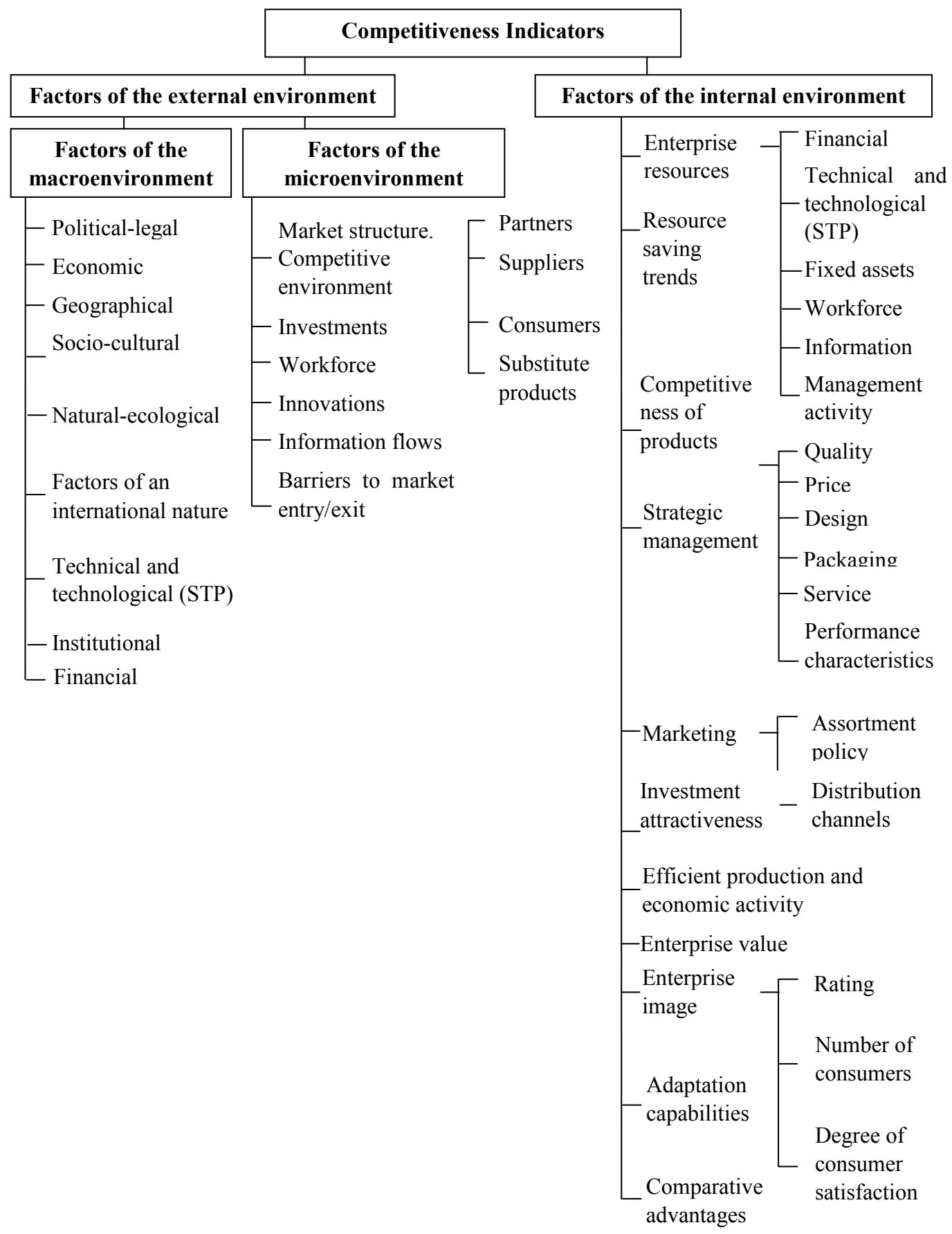

Figure 1. Factors of competitiveness in relation to forming a positive image in consumers' consciousness

Source: developed by the authors

(logo, packaging), which affects the formation of a positive image of the company and enhances the effectiveness of its customer contacts, and also increases the trust of partners and affects the growth of the company's reputation in the market (Figure 5). Figure 6 represents the package design. There are proposed 4 types of sweets in the box "Patria", comparable with the seasons, and in Figure 7, the associative names of sweets in the box are given. In accordance with the season, various flavours of sweets are offered:
"Patria Warm of Hearts" - adding champagne, "Patria Tenderness of Feelings" - cream filling, "Patria Fruit Flavour" - mixed fruit. To determine the cost of creating a brand name, costing method of cost calculation is used: the first cost item - the search for a name. Search for a name can be implemented either by the state of the company-manufacturer (for example, by the method of "brainstorming") or with the involvement of specialists. It is very difficult to estimate costs. In any case, the name variants that have passed the initial 

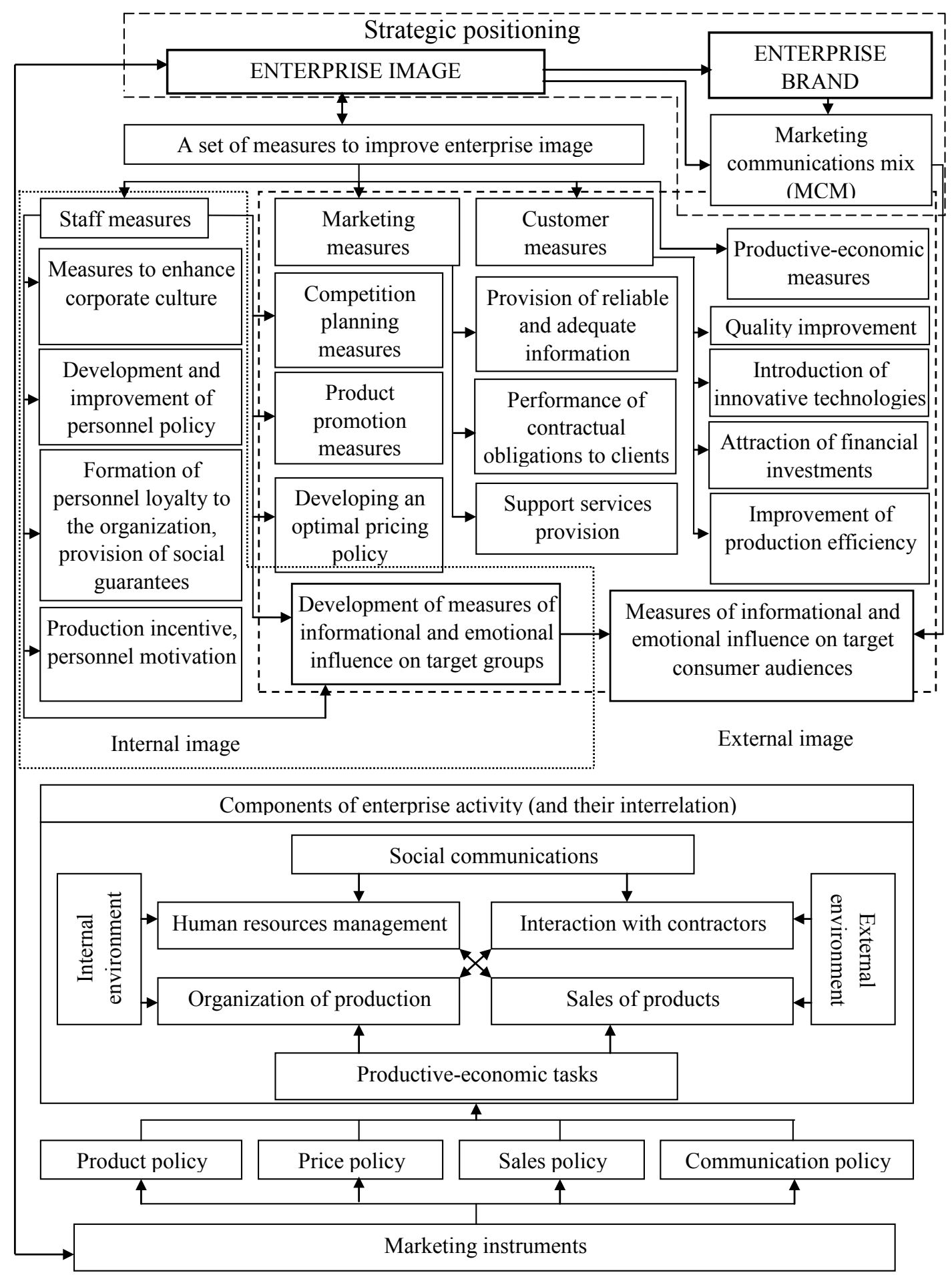

Figure 2. Enterprise image, measures of informational and emotional influence on target consumer audiences Source: developed by the authors

selection in the company should be tested on potential consumers of the product. The cost of the test, carried out by the specialized company, will be 1-10 thousand currency units depending on the type of research. The development and testing of the brand name "Patria" cost 2 thousand c.u. The second cost item is a graphical image of the name. The cost of developing a logo will be from
150 to 2500 c.u. The logo should also be thoroughly tested and then registered (300-1000 c.u.). In our case, the logo cost 400 c.u. The third cost item - the creation of a package for the product under a new name (1-10 thousand c.u.). The development of packaging of sweets in the box "Patria" cost 2 thousand c.u. The total cost of creating a brand name was 4.4 thousand c.u. 


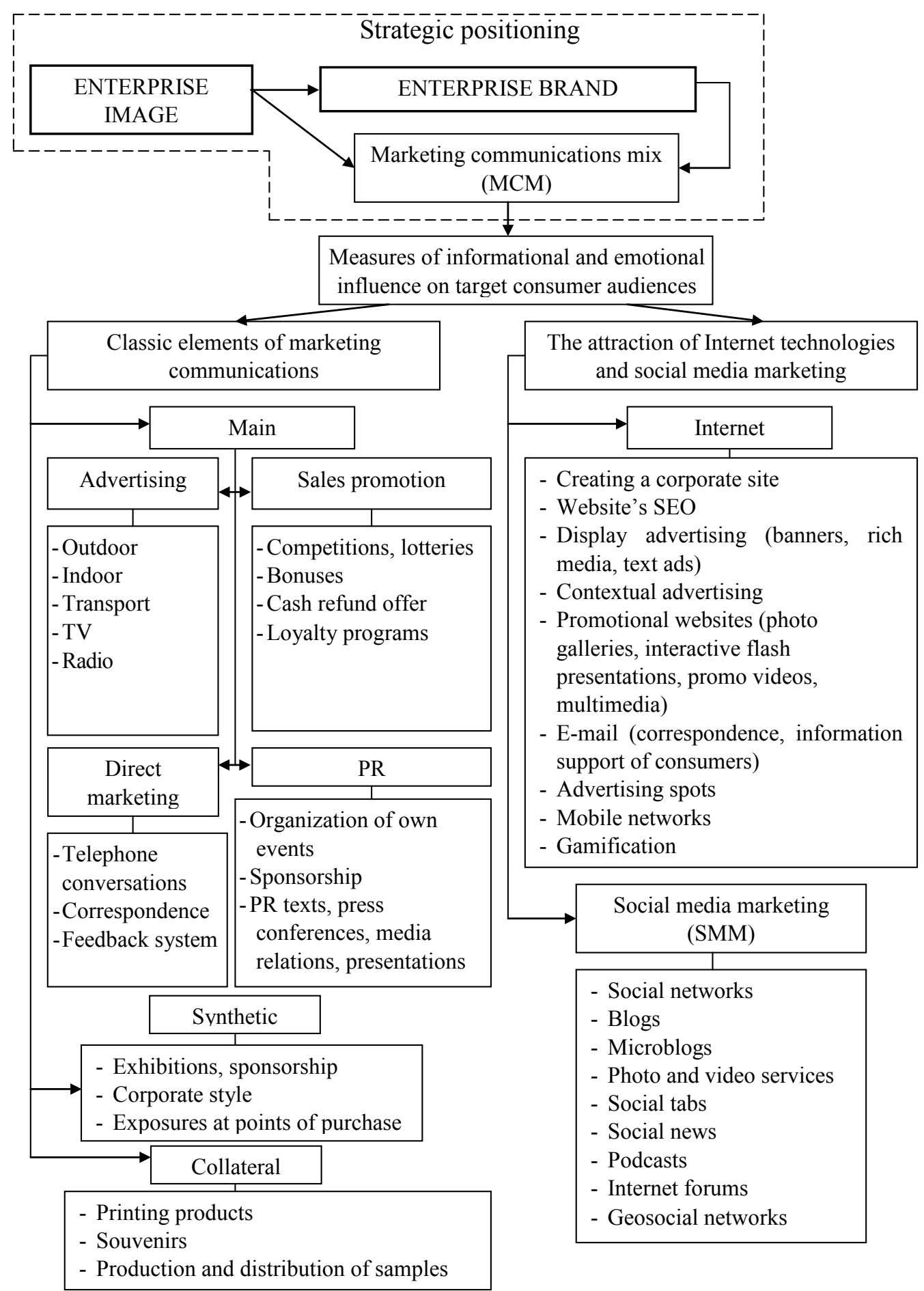

Figure 3. Enterprise brand, measures of informational and emotional influence on target consumer audiences Source: developed by the authors

\section{A methodological approach to evaluating the effectiveness of the marketing department for large industrial enterprises in the process of business management at the enterprise, taking into account enterprise value and brand value}

The paper distinguishes the following approaches to evaluating the performance of the marketing department on the example of industrial enterprises of Ukraine and proposes a generalized system of performance indicators for the marketing department, which is represented in Figure 8. The system for evaluating the performance of the marketing department, taking into account enterprise value and brand value, involves two levels of assessment: the first one allows evaluating 


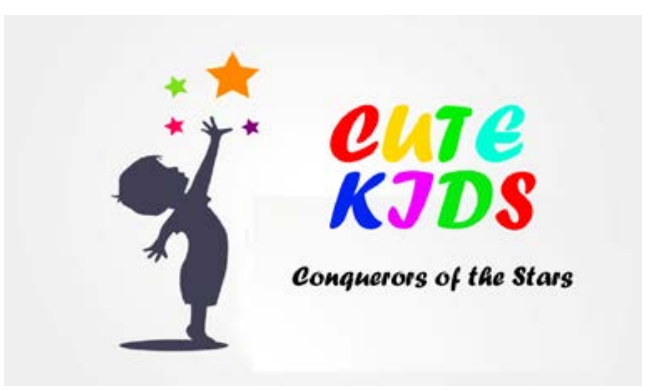

Figure 4. The logo of the Centre for Child Development "Cute Kids"

Source: developed by the authors

its performance in general (results of development of the marketing department), the second level takes into consideration the specifics of divisions of this department of the enterprise and allows determining their performance according to individual results, which are reflected in the basic social and economic performance indicators of the enterprise (Figure 9).
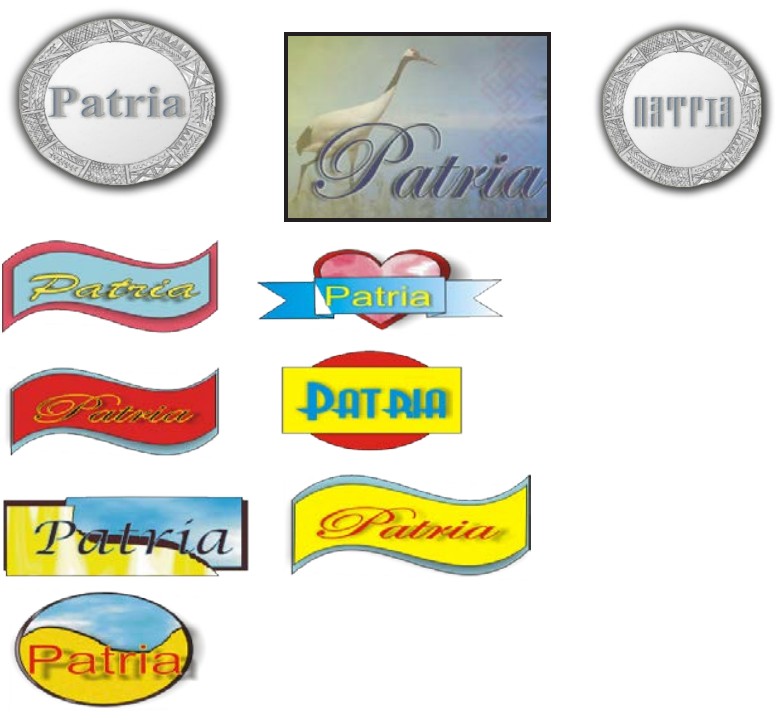

Figure 5. Logo of the brand "Patria"

Source: developed by the authors

The effectiveness of the development of the marketing department (first level of evaluation) is evaluated using the following indicators: development trend ratio, marketing efficiency ratio, management process productivity ratio, divi-

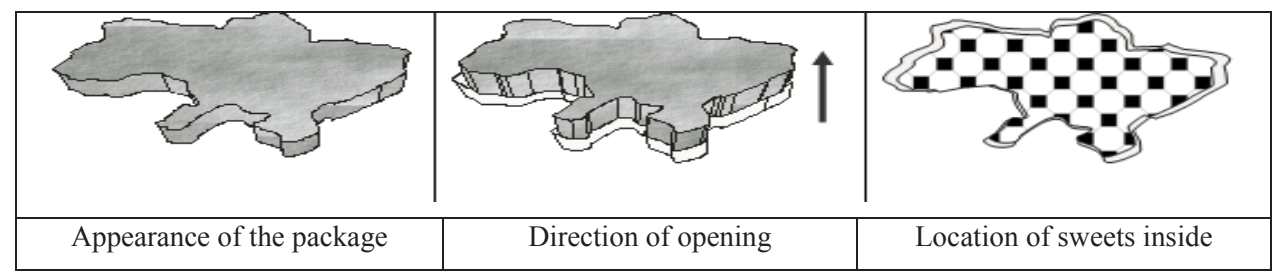

Figure 6. Package design

Source: developed by the authors sion productivity ratio,

and executive efficiency ratio. Table 1 represents a system of indicators for evaluating the performance of the marketing department of the first level taking into account enterprise value and brand value.

In order to determine indicators of the second level of evaluation, on the basis of the survey of employees and senior managers of a high strategic level of machine building enterprises and the specifics of this study, a system of performance indicators of the marketing department by divisions under the functional principle is formed, taking into consideration enterprise value, corporate image, and brand value (Table 2).

Enterprise image as an attribute of the enterprise is formed in different ways for different groups of the public. So, for partners, important are reliability and constructivity of the enterprise, goodwill (compliance with ethical business practices in the entrepreneurial activity), business partner loyalty, transparency, business activity of the enterprise.

Consumers consider enterprise image from the viewpoint of unique characteristics that in their view the enterprise products have: quality, brand awareness, support services and discount system provided by the enterprise, product price, consumer's vision of

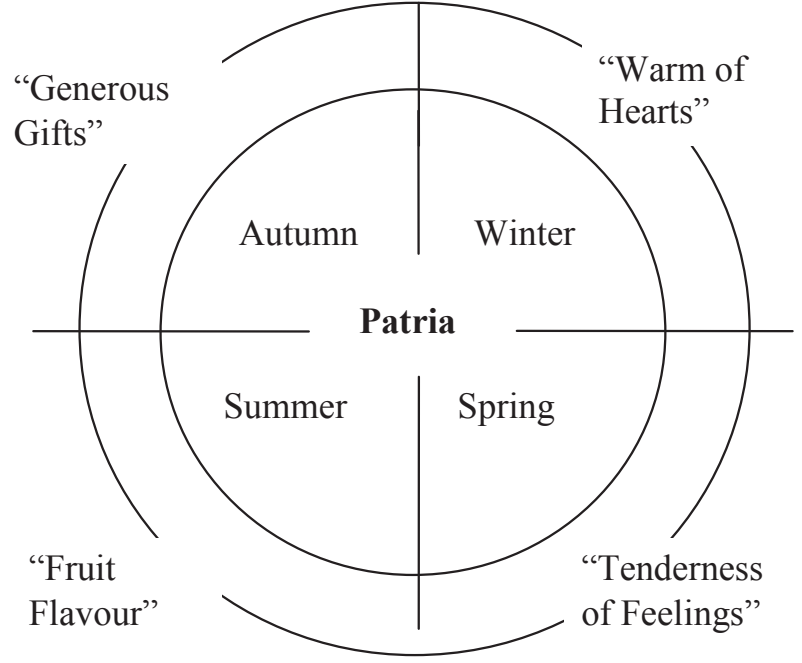

Figure 7. Seasonal names of sweets in the box "Patria"

Source: developed by the authors

the stated mission and strategies of the enterprise, corporate style, etc. Moreover, there is the staff's vision of their enterprise and its management. In such a way, it is appropriate to use the concept of a corporate image - a vision of an enterprise by various social groups. Enterprise corporate image evaluation should 


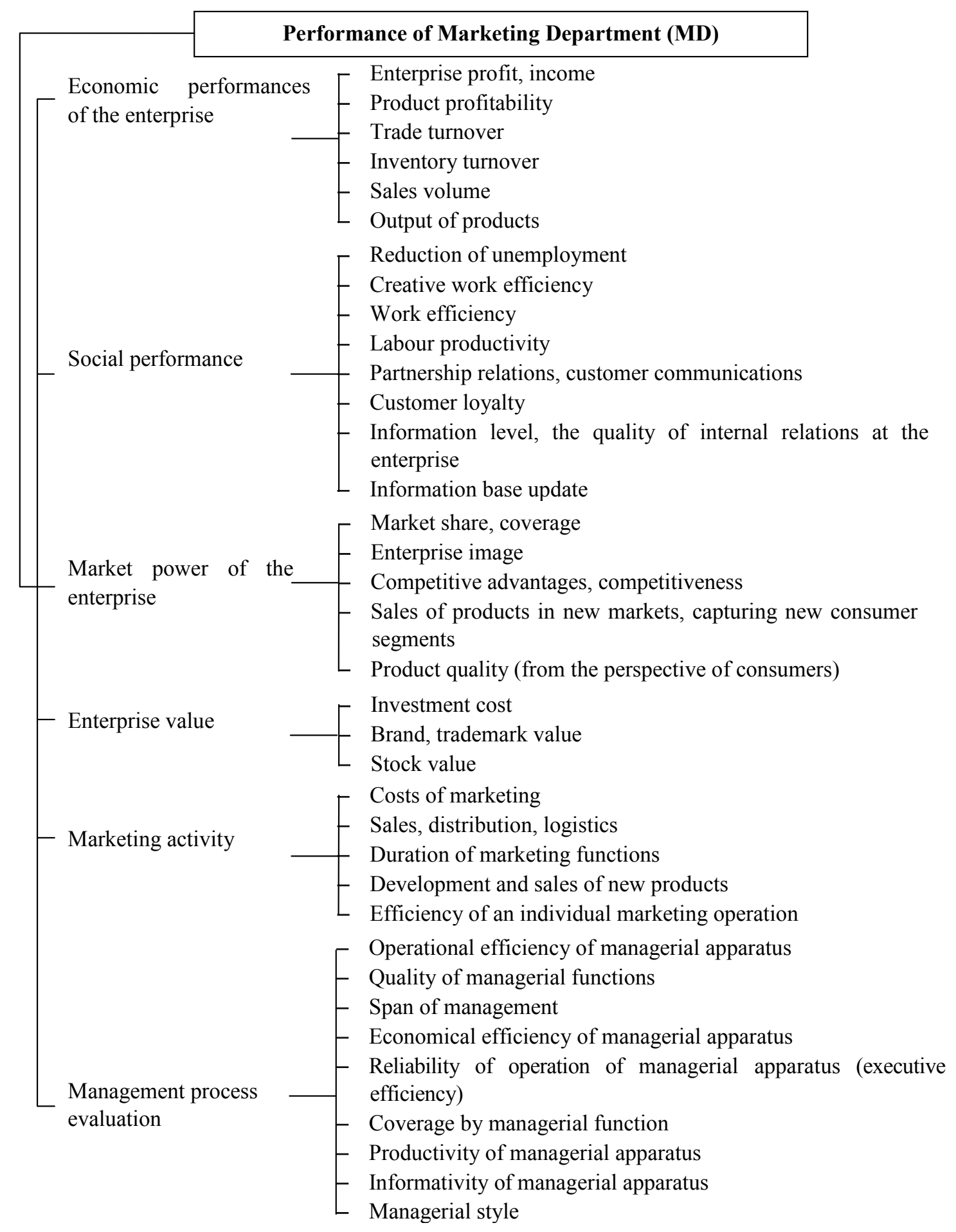

Figure 8. Performance indicators of the marketing department at the industrial enterprise, taking into account corporate image and enterprise value

Source: developed by the authors

be made in an assumption that image as an instrument of influence on the external environment should approximate to positive.

In order to determine the corporate image of the enterprise, experts (by social groups) are proposed to evaluate the degree of conformity of each evaluation parameter of the image with positive - give marks: " 5 " if this parameter fully corresponds to the positive image; " 4 " - if this parameter corresponds to the positive image not in full; " 3 " - if this parameter weakly corresponds to the positive image; "2" - if this parameter does not correspond to the positive image. 


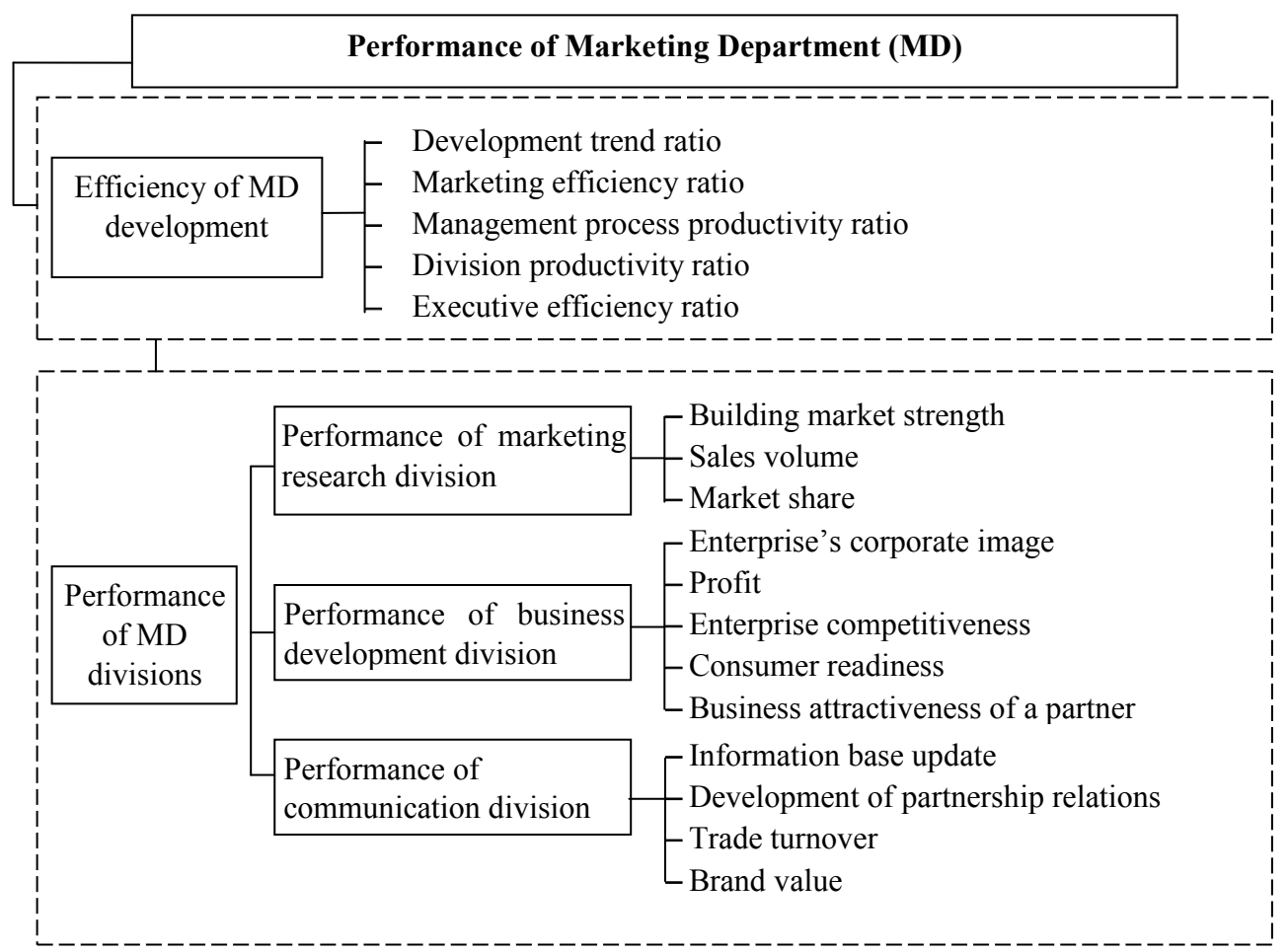

Figure 9. The system of indicators of performance evaluation of the marketing department taking into account corporate image and brand value

Source: developed by the authors

Table 1

Performance indicators of the marketing department (MD) by divisions in accordance with core objectives of machine building enterprises, taking into account enterprise value, corporate image, and brand value (based on classification features given in Figure 9)

\begin{tabular}{|c|c|c|c|}
\hline MD division & Functions & $\begin{array}{l}\text { Evaluation component } \\
\text { (by Fig. 9) }\end{array}$ & Performance indicators \\
\hline \multirow{2}{*}{ Marketing research division } & \multirow{2}{*}{$\begin{array}{l}\text { Conducting research on } \\
\text { the internal and external } \\
\text { environment, recommendations } \\
\text { for pricing and assortment policy }\end{array}$} & $\begin{array}{l}\text { Economic performances of the } \\
\text { enterprise }\end{array}$ & Sales volume \\
\hline & & $\begin{array}{l}\text { The market power of the } \\
\text { enterprise }\end{array}$ & $\begin{array}{l}\text { Market share } \\
\text { Building market strength }\end{array}$ \\
\hline \multirow{3}{*}{ Business development division } & \multirow{3}{*}{$\begin{array}{l}\text { Strategic analysis of business } \\
\text { environment, plan development, } \\
\text { coordination of the } \\
\text { implementation of marketing } \\
\text { programs, monitoring the } \\
\text { implementation of marketing } \\
\text { plans, strategic management of } \\
\text { marketing activities development }\end{array}$} & $\begin{array}{l}\text { The market power of the } \\
\text { enterprise }\end{array}$ & $\begin{array}{l}\text { Corporate image } \\
\text { Enterprise competitiveness }\end{array}$ \\
\hline & & $\begin{array}{l}\text { Economic performances of the } \\
\text { enterprise }\end{array}$ & Profit \\
\hline & & Social performance & $\begin{array}{l}\text { Consumer readiness } \\
\text { Business attractiveness of a } \\
\text { partner }\end{array}$ \\
\hline \multirow{3}{*}{ Communication division } & \multirow{3}{*}{$\begin{array}{l}\text { Information support, } \\
\text { development of communications } \\
\text { mix }\end{array}$} & $\begin{array}{l}\text { Economic performances of the } \\
\text { enterprise }\end{array}$ & Trade turnover \\
\hline & & Social performance & $\begin{array}{l}\text { Information base update } \\
\text { Development of partnership } \\
\text { relations }\end{array}$ \\
\hline & & Enterprise value & Brand value \\
\hline
\end{tabular}

Source: developed by the authors 
Table 2

The system of indicators for performance evaluation of the marketing department (first level)

\begin{tabular}{|c|c|c|c|c|}
\hline № & Indicator & $\begin{array}{l}\text { Calculation } \\
\text { formula }\end{array}$ & Symbols and explanations & Note \\
\hline 1 & 2 & 3 & 4 & 5 \\
\hline 1 & $\begin{array}{l}\text { Development } \\
\text { trend ratio (based } \\
\text { on changes trend } \\
\text { ratio proposed } \\
\text { by Informles } \\
\text { Consulting) }\end{array}$ & $I=\frac{H \cdot О б \cdot Ч Д}{C \kappa \cdot C n}$ & 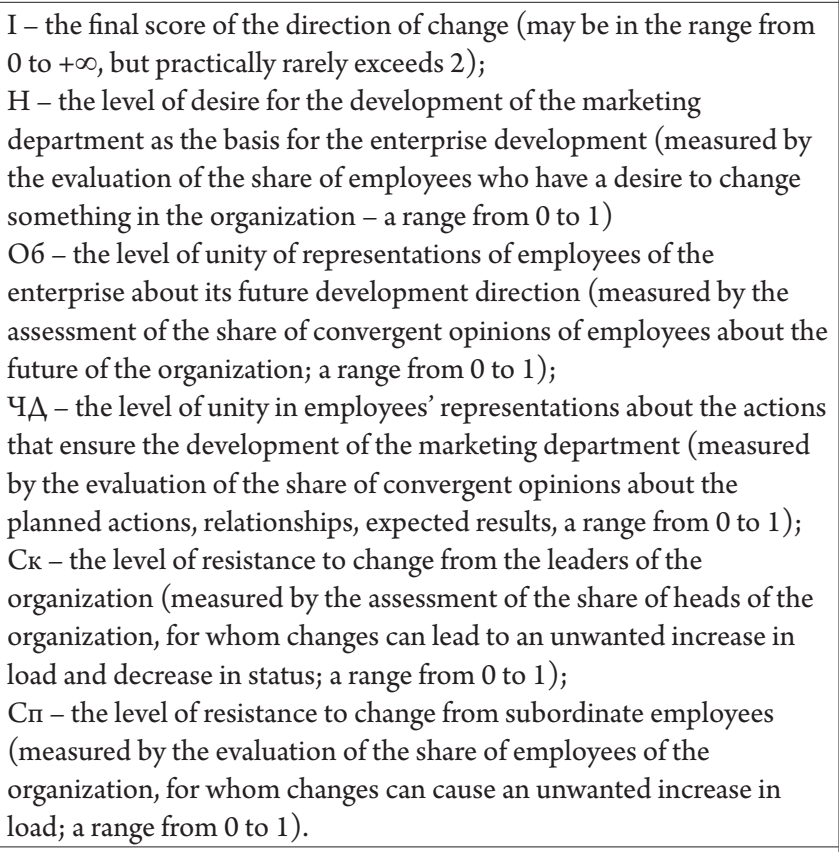 & $\begin{array}{l}\text { Changes are } \\
\text { successful and } \\
\text { purposeful, if I } \\
>1 \text {, and lead to } \\
\text { destabilization } \\
\text { of the state of } \\
\text { the organization } \\
\text { and decrease its } \\
\text { efficiency, if I }<1 \text {. }\end{array}$ \\
\hline 2 & $\begin{array}{l}\text { Marketing } \\
\text { efficiency ratio }\end{array}$ & $E_{\text {MД }}=\frac{M B}{M A}$ & $\begin{array}{l}\mathrm{E}_{\mathrm{M}_{\mathrm{A}}} \text { - efficiency of marketing activity at the enterprise; } \\
\mathrm{MB} \text { - marketing contribution for a period that is defined as the difference } \\
\text { between sales volume, marketing costs, and variable costs, hryvnias; } \\
\mathrm{MA} \text { - marketing assets, hryvnias. } \\
\text { The main marketing costs include: advertising costs; costs associated } \\
\text { with sales promotion; costs related to the organization of sales, } \\
\text { including premises and intermediaries; marketing research costs; } \\
\text { the shortfall in profits over discounts; } \\
\text { costs for preventing bad debts. } \\
\text { Marketing Assets (MA) include: stocks of finished products; accounts } \\
\text { receivable; vehicles used to organize sales and distribution of goods. }\end{array}$ & $\begin{array}{l}\text { The growth of the } \\
\text { ratio (in dynamics) } \\
\text { indicates the correct } \\
\text { marketing strategy, } \\
\text { and its reduction is a } \\
\text { signal for its revision } \\
\text { in order to improve }\end{array}$ \\
\hline 3 & $\begin{array}{l}\text { Management } \\
\text { process } \\
\text { productivity ratio }\end{array}$ & $\begin{array}{l}\text { Evaluates the } \\
\text { cost-effectiveness } \\
\text { of the management } \\
\text { process }\end{array}$ & $\begin{array}{l}\qquad K_{n p 1}=\frac{M B}{B_{a y}} \\
\mathrm{~K}_{\text {np1 }}-\text { management process productivity ratio; } \\
\mathrm{MB} \text { - marketing contribution for a period, hryvnias; } \\
\mathrm{B}_{\mathrm{ay}}-\text { costs of operation of the MD managerial apparatus, hryvnias. }\end{array}$ & $\begin{array}{l}\text { The higher the ratio, } \\
\text { the higher the MD } \\
\text { management process } \\
\text { productivity }\end{array}$ \\
\hline 4 & $\begin{array}{l}\text { Division } \\
\text { productivity ratio }\end{array}$ & $\begin{array}{l}\text { Evaluates the } \\
\text { performance of } \\
\text { the managerial } \\
\text { apparatus of } \\
\text { the marketing } \\
\text { department }\end{array}$ & $\begin{array}{l}\qquad K_{n p 2}=\frac{M B}{B_{a y}+B_{M M}} \\
\mathrm{~K}_{\text {пр2 }} \text { - the division's managerial apparatus productivity ratio; } \\
\mathrm{MB} \text { - marketing contribution for a period, hryvnias; } \\
\mathrm{B}_{\mathrm{ay}}-\text { costs of operation of the MD managerial apparatus, hryvnias; } \\
\mathrm{B}_{\mathrm{MM}}-\text { marketing costs. }\end{array}$ & $\begin{array}{l}\text { The higher the ratio, } \\
\text { the higher the MD } \\
\text { productivity }\end{array}$ \\
\hline 5 & $\begin{array}{l}\text { Executive } \\
\text { efficiency ratio }\end{array}$ & $\begin{array}{l}\text { Characterizes the } \\
\text { adequate response } \\
\text { of the managerial } \\
\text { apparatus to } \\
\text { market needs }\end{array}$ & $\begin{array}{l}\qquad K_{\theta \partial}=\frac{M_{\theta u}}{M_{n \imath}} \\
\mathrm{K}_{\mathrm{BA}} \text { - executive efficiency ratio; } \\
\mathrm{M}_{\mathrm{B}}-\text { the number of marketing activities conducted on time, units; } \\
\mathrm{M}_{\mathrm{nA}} \text { - the number of marketing activities to be implemented in the } \\
\text { reporting period according to the plan, units. }\end{array}$ & $\begin{array}{l}\text { The value of the ratio } \\
\text { can range from } 0 \text { to } \\
1 \text {; the closer it is to } \\
1, \text { the higher is the } \\
\text { level of performance } \\
\text { discipline, hence } \\
\text { the level of } \\
\text { quality of division } \\
\text { management }\end{array}$ \\
\hline
\end{tabular}

Source: developed by the authors 
Evaluation of the enterprise corporate image and each its component is determined as mean value:

$$
\bar{b}=\frac{1}{m n} \sum_{i=1}^{m} \sum_{j=1}^{n} b_{i j}
$$

where $b_{i j}$ - score of the $j$-th expert of the degree of correspondence of the $i$-th parameter with the positive image; $n$ - the number of experts; $m$ - the number of parameters under consideration.

On the basis of mean value obtained, conclusions are made on the degree of correspondence of the real enterprise image with the positive one according to the scale presented in the work (Shkardun, 2001).

Indicator "Building market strength" is evaluated from the viewpoint of the emergence of new markets and capturing new consumer segments. Indicator value can be identified with the help of production volume indicator through the ratio of actual production volume to the planned one at the moment of the study.

In order to evaluate information base update, it is proposed to use the following scoring system: "1" - "information base is updated regularly"; " 0.5 " - "information base is updated on request"; "0.25" - "information base is not updated at all."

Development of partnership relations can be evaluated as follows: "1" - partnership relations are evaluated positively, are stable, constructive, constantly renewed with constant partners; " 0.5 " - partnership relations extend - new partners are attracted; " 0.25 " partnership relations worsen - contracts are broken.

The results obtained allow drawing a conclusion that the formation of the marketing department at the industrial enterprise allowed improving the efficiency of marketing activity at the enterprise because values of indicators have a positive trend.

For determining the generalized quantitative evaluation of the development of the marketing department, it is proposed to calculate integrated development indicator of the marketing department as a sum of the ratio of marketing department's performance evaluation indicators, considered in dynamics, multiplied by their weighting coefficients:

$$
R=\sum_{j=1}^{n} k_{j} \cdot \frac{a_{j t}}{a_{j t+1}}
$$

where $R$ - integrated development indicator of the marketing department; $n$ - number of indicators of performance evaluation of the marketing department; $a_{j t}$ - standardized value of the $j$-th ratio in the period $t$; $a_{j t-1}-$ standardized value of the $j$-th ratio in the period $(t+1) ; k_{j}$ - weighting coefficient of the $j$-th ratio, which values are relevant for the period $[t ; t+1]$ (weighting coefficients are distributed by experts (management or a person who conduct research) depending on the set objectives of the marketing department for an estimated period in each case separately).

Since the ratios of performance evaluation of the marketing department are stimulators, let us apply standardization of data by using the following formula:

$$
p_{j}=\frac{q_{j}}{q_{j \max }},
$$

where $q_{j}$ - the value of the $j$-th ratio of performance evaluation of the marketing department; $q_{j \max }-$ the maximumvalue of the $j$-thratio of performanceevaluation of the marketing department.

Interpretation of values of integrated development indicator of the marketing department $R$ is carried out as follows (developed on the basis of Harrington's scale): $0 \leq R \leq 0,37$ - marketing department development is unsatisfactory, marketing management system at the enterprise is ineffective, which requires changes in the system of enterprise management and improvement of components of strategic management of marketing activity development; $0,38 \leq R \leq 0,64$ - positive development trend of the marketing department is observed, however, there is a need to develop individual measures for improving the operation of the marketing department - to increase the motivation of employees, explanatory work related to informing workers about the course of development, optimization of marketing costs, etc.; $0,64 \leq R \leq 1$ - development of the marketing department can be characterized as successful, effective, and purposeful.

Large business. Table 3 presents indicators of the effectiveness of development of the marketing department through the example of a large enterprise named Turboatom JSC for the second half of 2017 and the first half of 2018 (first level of evaluation according to Table 1 ), and also presents weighing coefficients of indicators determined on the basis of thoughts of senior management of this enterprise depending on the set objectives.

Let us calculate the integrated development indicator of the marketing department of Turboatom JSC:

Table 3

Initial data for calculating integrated development indicator of the marketing department

\begin{tabular}{|l|c|c|c|c|c|}
\hline \multicolumn{1}{|c|}{ Ratio name } & $\begin{array}{c}\text { Ratio value } \\
\text { (July-December 2017) }\end{array}$ & $\begin{array}{c}\text { Ratio value } \\
\text { (January-June 2018) }\end{array}$ & $\begin{array}{c}\text { Standardized value } \\
\text { of the ratio (July- } \\
\text { December 2017)* }\end{array}$ & $\begin{array}{c}\text { Standardized value } \\
\text { of the ratio (July- } \\
\text { December 2017) }\end{array}$ & $\begin{array}{c}\text { Weighing } \\
\text { coefficient }\end{array}$ \\
\hline Development trend ratio & 1,72 & 1,76 & 0,977 & 1 & 0,3 \\
\hline Marketing efficiency ratio & 2,08 & 2,31 & 0,9 & 1 & 0,45 \\
\hline $\begin{array}{l}\text { Management process } \\
\text { productivity ratio }\end{array}$ & 1921,9 & 2040,18 & 0,942 & 1 & 0,15 \\
\hline Division productivity ratio & 11,44 & 14,57 & 0,785 & 1 & 0,05 \\
\hline Executive efficiency ratio & 0,73 & 0,95 & 0,768 & 1 & 0,05 \\
\hline
\end{tabular}

Note. ${ }^{*}$ In this case, for $q_{i \max }$ the highest value of the indicator for the period under consideration was taken. 


$$
R=0,3 \cdot \frac{0,977}{1}+0,45 \cdot \frac{0,9}{1}+0,15 \cdot \frac{0,942}{1}+0,05 \cdot \frac{0,785}{1}+0,05 \cdot \frac{0,768}{1}=0,92 .
$$

So, the development of the marketing department at the industrial enterprise named Turboatom JSC taking into consideration enterprise value and brand value in general can be characterized as successful and purposeful.

Table 4 presents the results of analysis of performance evaluation indicators of the marketing department by the second level under the principle of correlation of the result to the set goal of the enterprise.

Evaluation of corporate image was carried out with the help of an anonymous survey of consumers of the production of Turboatom JSC, its business partners, and employees of the enterprise. Table 5 shows the results obtained.

Table 4

Performance evaluation of divisions of the marketing department

\begin{tabular}{|c|c|c|c|c|}
\hline \multirow{2}{*}{ Indicator } & \multirow[b]{2}{*}{ Method } & \multicolumn{2}{|c|}{ Indicator value } & \multirow{2}{*}{$\begin{array}{c}\text { Enterprise goal } \\
\text { (at the end } \\
\text { of 2018) }\end{array}$} \\
\hline & & 2017 & 2018 & \\
\hline Sales volume & Comparison in dynamics & 552 million hryvnias & 720 million hryvnias & $\begin{array}{l}\text { Increase sales } \\
\text { volume by } 30 \%\end{array}$ \\
\hline Market share & Comparison in dynamics & $57 \%$ & $57 \%$ & $\begin{array}{l}\text { Keep the } \\
\text { market share } \\
\text { at the level of } \\
2018\end{array}$ \\
\hline Profit & Comparison in dynamics & 145,383 million hryvnias & 125,74 million hryvnias & $\begin{array}{l}\text { Increase profit } \\
\text { by 3\% }\end{array}$ \\
\hline Trade turnover & Comparison in dynamics & 1,2 billion hryvnias & 1,5 billion hryvnias & $\begin{array}{l}\text { Increase the } \\
\text { indicator by } \\
10 \%\end{array}$ \\
\hline $\begin{array}{l}\text { Building market } \\
\text { strength (through } \\
\text { the indicator of } \\
\text { production volume) }\end{array}$ & Actual value/planned level & 30 production units & 32 production units & $\begin{array}{l}\text { Increase the } \\
\text { indicator by } 5 \%\end{array}$ \\
\hline $\begin{array}{l}\text { Enterprise } \\
\text { competitiveness }\end{array}$ & $\begin{array}{l}\qquad I=\sum_{i=1}^{n} \hat{x}_{i} d_{i} \\
\text { where } I-\text { integral estimation of } \\
\text { competitiveness of industrial enterprise; } \\
\hat{x}_{i}-\text { standardized estimation of the } \\
i \text {-th indicator of a component of } \\
\text { competitiveness of the internal and } \\
\text { external environment of the enterprise; } \\
d_{i} \text { - weighing coefficient of the } \\
i \text {-th indicator of a component of } \\
\text { competitiveness of the internal and } \\
\text { external environment of the enterprise; } \\
n \text { - the number of indicators for assessing the } \\
\text { competitiveness by the internal and external } \\
\text { environment of the enterprise (Raiko, D. } \\
\text { V. (2010), Enterprise, Partner, Consumer: } \\
\text { Theory and Practice of Interaction: } \\
\text { Monograph [Pidpryiemstvo, partner, } \\
\text { spozhyvach: teoriia ta praktyka vzaiemodii : } \\
\text { Monohrafiia]. Kharkiv : YNZhEK) } \\
\end{array}$ & 0,3265 & 0,3174 & $\begin{array}{l}\text { Increase } \\
\text { the level of } \\
\text { competitiveness } \\
\text { by } 0,15\end{array}$ \\
\hline Consumer readiness & $\begin{array}{l}\qquad I=\sum_{j=1}^{k} \overline{y_{j}} \cdot d_{j} \\
\text { where } I-\text { an indicator of business } \\
\text { attractiveness of a partner by resource and } \\
\text { organizational-managerial aspects; } \\
y_{j}-\text { standardized estimation of the } j \text {-th } \\
\text { indicator of a component of business } \\
\text { attractiveness of a partner; }\end{array}$ & 0,9736 & 0,9701 & $\begin{array}{l}\text { Increase } \\
\text { consumer } \\
\text { readiness by } \\
0,017 \text { points }\end{array}$ \\
\hline
\end{tabular}




\begin{tabular}{|c|c|c|c|c|}
\hline & & & & End of Table 1 \\
\hline & & & & Enterprise goal \\
\hline Indicator & Method & 2017 & 2018 & $\begin{array}{c}\text { (at the end of } \\
2018)\end{array}$ \\
\hline & $\begin{array}{l}d_{j} \text { - weighing coefficient of the } j \text {-th } \\
\text { indicator of a component of business } \\
\text { attractiveness of a partner; } \\
k \text { - the number of indicators of business } \\
\text { attractiveness of a partner. }\end{array}$ & & & \\
\hline $\begin{array}{l}\text { Business } \\
\text { attractiveness of a } \\
\text { partner }\end{array}$ & $\begin{array}{l}\qquad I=\sum_{j=1}^{k} \bar{y}_{j} \cdot d_{j} \text {, } \\
\text { where } I-\text { an indicator of consumer readiness } \\
\text { by components such as marketing loyalty, } \\
\text { economic performances of the enterprise, } \\
\text { and organization of enterprise operation; } \\
\overline{y_{j}} \text { - standardized estimation of the } j \text {-th } \\
\text { indicator of a component of consumer } \\
\text { readiness; } \\
d_{j} \text { - weighing coefficient of the } j \text {-th } \\
\text { indicator of a component of consumer } \\
\text { readiness; } \\
k \text { - the number of indicators of consumer } \\
\text { readiness. }\end{array}$ & 0,62 & 0,54 & $\begin{array}{l}\text { Increase } \\
\text { business } \\
\text { attractiveness of } \\
\text { a partner by } 0,1 \\
\text { point }\end{array}$ \\
\hline $\begin{array}{l}\text { Information base } \\
\text { update }\end{array}$ & $\begin{array}{l}\text { Scale: } \\
\text { "1" - "information base is updated } \\
\text { regularly"; } \\
\text { "0.5" - "information base is updated on } \\
\text { request"; } \\
\text { "0.25" - "information base is not updated } \\
\text { at all." }\end{array}$ & 0,5 & 1 & $\begin{array}{l}\text { Support for } \\
\text { information } \\
\text { base that } \\
\text { is updated } \\
\text { regularly }\end{array}$ \\
\hline $\begin{array}{l}\text { Development of } \\
\text { partnership relations }\end{array}$ & $\begin{array}{l}\text { Scale: "1" - partnership relations } \\
\text { are evaluated positively, are stable, } \\
\text { constructive, constantly renewed with } \\
\text { constant partners; } \\
\text { "0.5" - partnership relations extend - new } \\
\text { partners are attracted; } \\
\text { "0.25" - partnership relations worsen - } \\
\text { contracts are broken. }\end{array}$ & 0,5 & 0,5 & $\begin{array}{l}\text { Extension of } \\
\text { partnership } \\
\text { relations - } \\
\text { signing of a } \\
\text { contract with } \\
\text { China about } \\
\text { the supply of } \\
\text { turbines }\end{array}$ \\
\hline Brand value & Comparison in dynamics & & & $\begin{array}{l}\text { Increase brand } \\
\text { value by 5\% }\end{array}$ \\
\hline
\end{tabular}

The main goal of Turboatom JSC at the studied moment of time was to form a corporate image of the enterprise that corresponds to the positive image.

Depending on how the goals have been achieved (to what extent), we assess the performance indicators of the divisions of the marketing department on the following scale: "1" - the actual level of the indicator is equal to the planned one; " 0.75 " - the actual level of the indicator does not correspond to the planned, exceeds the expected level, indicating that there are disadvantages in activity planning; " 0.5 " - the actual level of the indicator does not correspond to the planned, is lower than the expected level, indicating inefficiency of activities and the presence of shortcomings in the business management; " 0.25 " - the actual level of the indicator does not correspond to the planned level but satisfies the senior management (the result is considered without reference to the set goals, which is caused by force majeure circumstances).

Also, it is proposed to calculate integrated performance indicator by divisions of the marketing department of the industrial enterprise using a formula, approbation of results is given in Table 6 .

$$
P_{j}=\frac{\sum_{i=1}^{n} a_{i}}{n}
$$

where $P_{j}$ - integrated performance indicator of the $j$-th division of the marketing department; $a_{i}$ - a score of the $i$-th indicator of the $j$-th division of the marketing department; $n$ - the number of indicators for evaluating the $j$-th division of the marketing department.

The obtained value of the indicator $P_{j}$ allows characterizing the division performance of the marketing department. Thus, if the value of $P_{j}$ is within the range. 
Table 5

Evaluation of the corporate image of Turboatom JSC

\begin{tabular}{|c|c|c|c|}
\hline $\begin{array}{c}\text { Component of } \\
\text { evaluation }\end{array}$ & Evaluation parameter & Correspondence & $\begin{array}{l}\text { Conclusion on the performance of the } \\
\text { business development division }\end{array}$ \\
\hline 1 & 2 & 3 & 4 \\
\hline \multirow{7}{*}{$\begin{array}{l}\text { Enterprise } \\
\text { image among } \\
\text { consumers }\end{array}$} & Quality, characteristics of production & fully corresponds & \multirow{7}{*}{$\begin{array}{l}\text { The enterprise image is formed such that } \\
\text { doesn't fully correspond to the positive } \\
\text { one, first of all, by virtue of the lack of } \\
\text { consumers' vision of the firm's mission } \\
\text { and strategies. More attention should be } \\
\text { paid to solving this issue. }\end{array}$} \\
\hline & Brand awareness & corresponds not in full & \\
\hline & Service & corresponds not in full & \\
\hline & Discount system & corresponds not in full & \\
\hline & Price & corresponds not in full & \\
\hline & $\begin{array}{l}\text { Consumers' vision of the stated mission } \\
\text { and strategies of the enterprise }\end{array}$ & weakly corresponds & \\
\hline & Corporate style of the enterprise & corresponds not in full & \\
\hline \multirow{5}{*}{$\begin{array}{l}\text { Enterprise } \\
\text { image among } \\
\text { partners }\end{array}$} & Level of loyalty to business partners & fully corresponds & \multirow{5}{*}{$\begin{array}{l}\text { Business partners' visions of the } \\
\text { enterprise don't correspond in full to the } \\
\text { positive image, which is determined by } \\
\text { inefficient transparency of the enterprise. } \\
\text { It is necessary to improve the quality of } \\
\text { information link with partners. }\end{array}$} \\
\hline & Enterprise reliability & corresponds not in full & \\
\hline & Level of the prestige of the enterprise & corresponds not in full & \\
\hline & $\begin{array}{l}\text { Business partners' vision of the stated } \\
\text { mission and strategies of the enterprise }\end{array}$ & corresponds not in full & \\
\hline & Enterprise transparency & weakly corresponds & \\
\hline \multirow{8}{*}{$\begin{array}{l}\text { An internal } \\
\text { image of the } \\
\text { enterprise }\end{array}$} & $\begin{array}{l}\text { Level of executive management loyalty to } \\
\text { personnel }\end{array}$ & corresponds not in full & \multirow{8}{*}{$\begin{array}{l}\text { Image among the employees is not } \\
\text { close enough to the positive one over } \\
\text { the weak transparency of leadership, } \\
\text { unestablished system of moral and } \\
\text { material incentives for personnel, and } \\
\text { unclear employees' vision of missions } \\
\text { and tasks solved by the firm, which } \\
\text { requires renewed approaches to } \\
\text { management and work organization. }\end{array}$} \\
\hline & $\begin{array}{l}\text { Level of transparency of executive } \\
\text { management }\end{array}$ & weakly corresponds & \\
\hline & Provided social guarantees & corresponds not in full & \\
\hline & Career prospects & corresponds not in full & \\
\hline & The system of wages and moral incentives & weakly corresponds & \\
\hline & Level of the prestige of the firm & weakly corresponds & \\
\hline & The moral environment at the enterprise & corresponds not in full & \\
\hline & $\begin{array}{l}\text { Staff's vision of the stated mission and } \\
\text { strategies of the enterprise }\end{array}$ & corresponds not in full & \\
\hline
\end{tabular}

Table 6

Evaluation of performance of divisions of the marketing department at Turboatom JSC

\begin{tabular}{|c|c|c|c|}
\hline MD division & Performance indicators & Indicator score (scale) & Integrated indicator \\
\hline \multirow{3}{*}{$\begin{array}{l}\text { Marketing research } \\
\text { division }\end{array}$} & Sales volume & 1 & \multirow{3}{*}{$P_{1}=\frac{1+1+0,75}{3}=0,92$} \\
\hline & Market share & 1 & \\
\hline & Building market strength & 0,75 & \\
\hline \multirow{5}{*}{$\begin{array}{l}\text { Business } \\
\text { development } \\
\text { division }\end{array}$} & Corporate image & 0,5 & \multirow{5}{*}{$P_{2}=\frac{0,5+0,5+0,5+0,5+0,5}{5}=0,5$} \\
\hline & Enterprise competitiveness & 0,5 & \\
\hline & Profit & 0,5 & \\
\hline & Consumer readiness & 0,5 & \\
\hline & Business attractiveness of a partner & 0,5 & \\
\hline \multirow{4}{*}{$\begin{array}{l}\text { Communication } \\
\text { division }\end{array}$} & Trade turnover & 0,75 & \multirow{4}{*}{$P_{3}=\frac{0,75+1+1+0,5}{4}=0,81$} \\
\hline & Information base update & 1 & \\
\hline & Development of partnership relations & 1 & \\
\hline & Brand value & 0,5 & \\
\hline
\end{tabular}

On the basis of the research results, the conclusion was made on the satisfactory work of all divisions of the marketing department, which provides in general the corporate image, the enterprise value, and the brand value on the example of the industrial enterprise named Turboatom JSC.

\section{Conclusions}

This work is devoted to studying the theory of interaction of image, brand of an enterprise based on marketing as a philosophy of management, where it is identified that enterprise image is an integral part of enterprise brand, and their interaction is taking place through marketing communications mix and implementation practices on the example of business projects of enterprises with different levels of business activity in Kharkiv and Kharkiv region of Ukraine: small, medium-sized, and large business (small the Centre for Child Development "Cute Kids", medium Association of Confectionery Enterprises "Solodkyi Svit", large - Turboatom JSC). 
The work results are the development of methodological approach to evaluating the effectiveness of the marketing department in the process of business management at the enterprise, taking into account the enterprise value and brand value for large industrial enterprises, the peculiarity of which is the ability to investigate the relationship between the effectiveness of the development of the marketing department (organizational and managerial aspect) and the operating results of its divisions (economic aspect) and take into account the identified causal relationships in the process of enterprise activity. The system for evaluating the performance of the marketing department, taking into account enterprise value and brand value, involves two levels of assessment: the first one - to determine its performance in general, that is, the effectiveness of its development, the second - takes into account the specifics of divisions of this department of the enterprise and allows determining their performance according to individual results, that is, the effectiveness of divisions, which is reflected in the basic social and economic performance indicators of the enterprise. The calculation is proposed by the following indicators: an integral indicator of the effectiveness of the development of the marketing department, and by performance indicators of marketing research division (sales volume, market share, strengthening of market positions), the work of the business development division ("corporate image", "enterprise competitiveness", "profit", "consumer readiness”, "partner's business attractiveness"), communication division (trade turnover, updating of the information base, development of partnership relations, brand value). The approbation of the developed methodological approach is made on the example of the large industrial enterprise named Turboatom JSC that confirms its practical importance.

\section{References:}

Aleshina, I. V. (1998). Korporativnyi imidzh [Corporate Image]. Marketing, 1, 50-53.

Babich, K., Lakhno, I. (1997). Otsenka imidzha promyshlennoho predpriyatiya [Evaluation of image of industrial enterprise]. Biznes-Inform, 8, 47-58.

Dowling, G. R. (2006). Nauka i iskusstvo marketinga [The art and science of marketing]. St. Peterburg: Vektor.

Dobrianska, O. V. (2001). V Ukraini tsina rozrobky brendu zavyshchena chy ne vdvichi [In Ukraine, the price of brand development is overstated almost twice]. Halytski kontrakty, 25, 18-19.

Doyle, P. (1999). Menedzhment: strategiya i taktika [Management: strategy and tactics]. St. Peterburg: Piter.

Domnin, V. N. (2004). Brending: novye tekhnologii v Rossii [Branding: new technologies in Russia]. St. Peterburg: Piter.

Jones, J. (2005). Rol reklamy v sozdanii silnykh brendov [How to Use Advertising to Build Strong Brands]. Moscow: Viliams.

Gardner, B., Levy, S. (1995). The product and the brand. Harvard Business Review, Vol. 33.

Interbrand World's Most Valuable Brands 2001 Methodology. Retrieved from: www.interbrand.com.

Kupchynska, M. (2004). Shcho brend pryideshnii nam hotuie? [What does the future brand bring?]. Marketynh $v$ Ukraini, 5, 41-43.

Ogilvy, D. (2003). Ogilvi o reklame [Ogilvy on Advertising]. Moscow: Eksmo.

Oliver, S. (2003). Strategiya v pablik rileishnz [Public Relations Strategy]. St. Peterburg: Piter.

Posylannia na dzherelo Premii Shvedskoho natsionalnoho banku z ekonomichnykh nauk pamiati Alfreda Nobelia [Laureate of the Nobel Prize in Economics R. Thaler Reference to The Sveriges Riksbank Prize in Economic Sciences in Memory of Alfred Nobel]. Retrieved from: https://www.nobelprize.org/nobel_prizes/economicsciences/laureates/2017/

Raiko, D. V. (2010). Pidpryiemstvo, partner, spozhyvach: teoriia ta praktyka vzaiemodii: Monohrafiia [Enterprise, partner, consumer: theory and practice of interaction: monograph]. Kharkiv: YNZhEK.

Sandage, C. (2001). Reklama: teoriya i praktika [Advertising theory and practice]. Moscow: Sirin.

Shkardun, V. D. (2001). Otsenka i formirovanie korporativnogo imidzha predpriyatiya [Evaluation and creation of enterprise corporate image]. Marketing $v$ Rossii i za rubezhom, 3, 68-77.

Ulianova, K. M. (2002). Torhova marka yak osnova marochnoho kapitalu [Trademark as a basis of brand capital]. Marketynh v Ukraini, 3, 41-42.

Zaruba, V. Ya., Shasha, O. I. (2001). Upravlinska kontseptsiia imidzhbildynhu [Image-building management concept]. Biznes-Inform, 1, 90-94.

Zozulov, O. (2003). Urovni formirovaniya brendov v sovremennykh usloviyakh [Brand formation levels under current conditions]. Otdel marketinga, 7, 19-22.

Zozulov, O. V. (2002). Brendynh ta antybrendynh: shcho vybraty v Ukraini [Branding and anti-branding: what to choose in Ukraine]. Marketynh v Ukraini, 4, 26-29.

Zozulov, O. V., Pysarenko, N. L. (2004). Rynkove pozytsionuvannia: z choho pochynaietsia stvorennia uspishnykh brendiv [Market positioning: how to begin building successful brands]. Kyiv: Znannia-Pres. 